\title{
Effect of Tannin in Green Tea By-Product in Combination with Bio-Char Supplemented into Basal Beef Cattle Diet on Nutrient Digestibility, Methane Production and Animal Performance
}

\author{
M. A. Khoa1, N. H. Quang', T. V. Thang', T. V. Phung3, T. T. Kien² \\ ${ }^{1}$ Thai Nguyen University, Thai Nguyen City, Vietnam \\ ${ }^{2}$ University of Agriculture and Forestry-TNU, Thai Nguyen City, Vietnam \\ ${ }^{3}$ Institute of Life Sciences-TNU, Thai Nguyen City, Vietnam \\ Email: khoa.mai@tnu.edu.vn
}

How to cite this paper: Khoa, M.A., Quang, N.H., Thang, T.V., Phung, T.V. and Kien, T.T. (2018) Effect of Tannin in Green Tea By-Product in Combination with Bio-Char Supplemented into Basal Beef Cattle Diet on Nutrient Digestibility, Methane Production and Animal Performance. Open Journal of Animal Sciences, 8, 206-214.

https://doi.org/10.4236/ojas.2018.83015

Received: April 16, 2018

Accepted: June 23, 2018

Published: June 26, 2018

Copyright (๑) 2018 by authors and Scientific Research Publishing Inc. This work is licensed under the Creative Commons Attribution International License (CC BY 4.0).

http://creativecommons.org/licenses/by/4.0/ c) (†) Open Access

\begin{abstract}
The experiment was conducted by using 20 bulls of Lai Sind cattle (a cross breed between Red Sindhi and local Vietnam yellow cattle) from 15 - 16 months of age, weighed approximately $154-156 \mathrm{~kg}$, housed individually with provision of adequate feed trough and free access to water to evaluate the effect of tannin sourced from green tea by-product and addition of bio-char on methane production and animal performance. The experimental diets were formulated by replacing elephant grass in basal diet by bio-char and green tea by-product with the replacement of $0.5-1$ bio-char and 3\%-5\% green tea by-products, respectively to make the content of tannin in the diet of $7.3 \mathrm{~g}$ and $12.5 \mathrm{~g}$ tannin per kg dry matter. Results from this study revealed that bio-char and green tea by-product included into the diet with different levels had significantly affected on the feed intake, as the increasing level of tannin in the diet tended to increase the feed intake. The inclusion of green tea by-product in the diet which resulted in the content of tannin in the diet of $12.5 \mathrm{~g} / \mathrm{kg} \mathrm{DM}$ had significantly reduced methane emission without altering animal performance, thus the inclusion of $0.5 \%$ bio-char and $5 \%$ of green tea by-product can be applied in order to mitigate methane emission, thus contributed to environment protection.
\end{abstract}

\section{Keywords}

Green Tea By-Product, Bio-Char, Tannin, Methane Emission, Animal Performance 


\section{Introduction}

Methane production in ruminant can be reduced from $12 \%$ - 37\% by altering ruminant diets [1] [2] [3]. It has been reported that the inclusion of tannin into ruminant diet could reduce rumen methane production in both in vitro and in vivo conditions. Tannin directly affects the formation of methane or indirectly altered the number of protozoa and microbial cellulose [4]. Therefore, tannin, in combination with bio-char presented in the diet was believed to effectively reduce rumen methane production [5] without lowering nutrient digestibility.

The source of tannin in the diet materials plays an important role on methane production in both in vitro and in vivo so that tannin could be presented in the diet up to $15 \%$ depended on its source [6] [7].

Bio-char was known as an antidote additive and it has been extensively studied in ruminant nutrition [8] [9]. Thank to its absorption capacity, bio-char played as gas absorptive agent in the rumen [10].

Currently, Thai Nguyen-Vietnam has a large area of tea production, thanks to the suitable natural conditions. Annually, tea production left over tons of green tea by-products (matured leaves and branches). This could be the important source for animal feed especially it can be used for ruminant supplement diet.

This tannin source, in combination with bio-char, would improve feed intake, thus improve animal productivity [11]. Therefore, in this study, green tea by-product was the source of tannin tested in order to reduce methane emission without altering rumen microbial system and thus the diet digestibility.

\section{Materials and Methods}

\subsection{Animals and Housing}

The experiment was conducted by using 20 bulls of Lai Sind cattle (a cross breed between Red Sindhi and local Vietnam yellow cattle) from 15 - 16 months of age, weighed approximately $154-156 \mathrm{~kg}$, housed individually with provision of adequate feed trough and free access to water. Each pen was equipped with respiratory chamber for methane emission evaluation, the bulls was diet acclimatized for 15 days before any measurements taken place. All experimental animals were vaccinated, de-wormed and were cared to comply with Vietnamese standard for experimental animals. The experiment was conducted in 90 days at the Experimental Unit of the Center for Animal production in the Northern Mountainous region-Vietnam.

\subsection{Experimental Diets}

The basal diet was formulated from elephant grass, maize bran, cassava by-product, and the experimental diets were formulated by replacing elephant grass by bio-char and green tea by-product with the replacement of $0.5-1$ bio-char and 3\% - 5\% green tea by-products, respectively.

The basal diet was prepared to comply with NRC (1996) for growing cattle (10 
- $11 \mathrm{MJ} \mathrm{ME} / \mathrm{kg} \mathrm{DM}$ and $12 \%$ - 14\% crude protein contents). The diets composition is presented in Table 1.

Bulls were assigned randomly to access either 1 of 5 diets twice daily (8:00 AM and 4:00 PM) with free access to water, the refusal was weighed twice daily in accordance to feeding schedule.

\subsection{Monitoring}

Nutrients intake includes gross energy, metabolism energy, dry matter, and organic matter, crude protein, NDF, ADF, crude fibre, total ash was recorded and calculated.

Animals were weighed monthly interval to determine production performance.

For methane emission measurement, each month, each bull was entered respiratory chamber for 24 hours, where total methane emission (liter/animal/day) was recorded based on the different of air inlet and outlet automatic recorder (20 minutes interval for inlet air and 5 minutes interval for outlet air). Air sample was collected and analyzed automatically at the beginning of the experiment (the diet acclimatize period) and at the end of the experimental period.

\subsection{Statistical Analysis}

Data analysis was performed followed equation: $Y_{i j}=\mu+T_{i}+\varepsilon_{i j}$.

Where: $(i j)$ observation from diets, $(i)$ replication, $(\mu)$ Overall mean, $\left(T_{i}\right)$ mean of each formula, $\left(\varepsilon_{i j}\right)$ random errors. The comparison was done following Duncan's New Multiple Range Test (DMRT) [12].

Table 1. The composition of experimental diets.

\begin{tabular}{|c|c|c|c|c|c|}
\hline \multirow{2}{*}{ Ingredients } & \multicolumn{5}{|c|}{ Composition (\% DM) } \\
\hline & Control & DIET1 & DIET2 & DIET3 & DIET4 \\
\hline 1) Elephant grass & 89.0 & 85.5 & 85.0 & 83.5 & 83.0 \\
\hline 2) Cassava & 1.8 & 1.8 & 1.8 & 1.8 & 1.8 \\
\hline 3) Soybean meal & 3.9 & 3.9 & 3.9 & 3.9 & 3.9 \\
\hline 4) Maize bran & 2.5 & 2.5 & 2.5 & 2.5 & 2.5 \\
\hline 5) Rice bran & 2.8 & 2.8 & 2.8 & 2.8 & 2.8 \\
\hline 6) Green tea by-product & 0 & 3 & 3 & 5 & 5 \\
\hline 7) Bio-char & 0 & 0.5 & 1 & 0.5 & 1 \\
\hline Total & 100 & 100 & 100 & 100 & 100 \\
\hline Dry matter & 25.2 & 25.5 & 25.7 & 25.4 & 25.2 \\
\hline $\mathrm{CP}$ & 13.0 & 13.02 & 13.05 & 13.1 & 13.05 \\
\hline $\mathrm{ME}$ & $10.30(\mathrm{MJ} / \mathrm{kg})$ & $10.32(\mathrm{MJ} / \mathrm{kg})$ & $10.32(\mathrm{MJ} / \mathrm{kg})$ & $\begin{array}{c}10.35 \\
(\mathrm{MJ} / \mathrm{kg})\end{array}$ & $\begin{array}{c}10.35 \\
(\mathrm{MJ} / \mathrm{kg})\end{array}$ \\
\hline Tannin & & 0.73 & 0.73 & 1.25 & 1.25 \\
\hline
\end{tabular}




\section{Results and Discussion}

\subsection{Effect of Green Tea By-Product and Bio-Char Supplement on Nutrients Intake}

The effect of green tea by-product and bio-char supplement on feed and nutrients intake is presented in Table 2.

It can be seen from the Table that the different levels of green tea by-product which led to the difference of tannin content in the diets had no effect on voluntary feed intake as the increasing levels of tannin and bio-char the feed intake also did not tend to increase $(p>0.05)$. This could be explained that the tannin and bio-char contents in the diets did not affect the palatability of the diets as in our trial, the tannin content was 7.3 to $12.5 \mathrm{~g} / \mathrm{kg} \mathrm{DM}$, which was by far medium tannin content of $<50 \mathrm{~g} / \mathrm{kg}$ DM that could reduce voluntary feed intake as reported by Barry \& Manle [13], Barry, Manley, \& Duncan [14], Waghorn, Shelton, \& McNabb [15]. The increasing level of bio-char content also did not affect the voluntary feed intake of the tested animals as it was supported by findings from Leng et al. [16], even though, in our experiment the supplement of bio-char was $0.4 \%$ higher than their report. The addition of bio-char into diet had been used widely in order to improve the fermentation kinetic of the diets in the rumen. Bio-char has been utilized as feed additive to increase microbial habitats [17], thus bio-char may improve microbial growth efficiency [16], and thus improved rumen digestibility and then voluntary intake was compensated.

\subsection{Effect of Green Tea By-Product and Bio-Char Supplement on the Growth of Cattle}

Data of the effect of green tea by-product and bio-char supplement on the animal grows is presented in Table 3.

Data present in Table 3 showed that after 30 days of experimental period there was no significant difference in animal bodyweight. After 60 days of experimental period, there was an increase in BW of animals fed with diets containing higher levels of green tea by-product (higher containing tannin diet) compared to the Control. Animals fed with diets containing 3\% green tea by-product (or $0.73 \%$ tannin) and $0.5 \%$ bio-char content had the similar bodyweight compare to those in the Control $(p>0.05)$.

Table 2. Feed and nutrients intake of Lai Sind bulls.

\begin{tabular}{cccccccccccc}
\hline \multirow{2}{*}{ Categories } & \multicolumn{2}{c}{ Control } & \multicolumn{2}{c}{ DIET1 } & \multicolumn{2}{c}{ DIET2 } & \multicolumn{2}{c}{ DIET3 } & \multicolumn{2}{c}{ DIET4 } \\
\cline { 2 - 11 } & Mean & Se & Mean & Se & Mean & Se & Mean & Se & Mean & Se \\
\hline $\begin{array}{c}\text { DM intake } \\
\text { per day (kg) }\end{array}$ & 2.86 & 0.008 & 2.86 & 0.011 & 2.88 & 0.006 & 2.89 & 0.006 & 2.90 & 0.009 \\
CP (g/day) & 371 & 1.2 & 371 & 1.4 & 374 & 1.2 & 375 & 1.2 & 377 & 1.4 \\
ME (MJ/day) & 29.45 & 0.08 & 29.51 & 0.11 & 29.72 & 0.06 & 29.91 & 0.07 & 30.01 & 0.09 \\
\hline
\end{tabular}

Note: The different subscript letters in the same row are significant different $(p<0.05)$. 
Table 3. The effect of green tea by-product and bio-char on animal growth.

\begin{tabular}{ccccccccccccc}
\hline \multirow{2}{*}{ Category } & \multicolumn{2}{c}{ Control } & \multicolumn{2}{c}{ DIET1 } & \multicolumn{2}{c}{ DIET2 } & \multicolumn{2}{c}{ DIET3 } & \multicolumn{2}{c}{ DIET4 } & \multirow{2}{*}{ P (Sig.) } \\
\cline { 2 - 11 } & Mean & Se & Mean & Se & Mean & Se & Mean & Se & Mean & Se & \\
\hline Initial BW & 154.6 & 0.24 & 153.7 & 0.75 & 153.0 & 1.09 & 153.2 & 0.43 & 154.2 & 1.11 & 0.954 \\
After 30days & 174.6 & 0.99 & 174,5 & 0.65 & 175.8 & 0.77 & 175.0 & 0.41 & 174.0 & 0.91 & 0.138 \\
After 60days & $190.3^{\mathrm{d}}$ & 0.55 & $193.7^{\mathrm{cd}}$ & 1.09 & $197.5^{\mathrm{b}}$ & 1.40 & $200.2^{\mathrm{a}}$ & 0.85 & $194.6^{\mathrm{c}}$ & 0.55 & 0.000 \\
After 90day & $211.0^{\mathrm{c}}$ & 0.41 & $213.2^{\mathrm{b}}$ & 1.74 & $218.0^{\mathrm{a}}$ & 0.74 & $221.1^{\mathrm{a}}$ & 0.43 & $214.8^{\mathrm{b}}$ & 0.59 & 0.000 \\
\hline
\end{tabular}

Note: The different subscript letters in the same row are significant different $(p<0.05)$.

After 90 days of the experimental period, this difference was significant among those fed with diet containing $3 \%$ green tea by-product (or $0.73 \%$ tannin) and $1 \%$ bio-char; and those fed with $5 \%$ green tea by-product (or $1.25 \%$ tannin) and $0.5 \%$ bio-char. It can be inferred that the increasing of tannin content with $0.5 \%$ bio-char in the diet would give the best growth in cattle.

\subsection{The Effect of Green Tea By-Product and Bio-Char Supplement on Methane Emission}

The data of methane emission from experimental animals fed with different diets containing green tea by-product and bio-char is presented in Table 4.

It can be inferred from Table 4 that methane emission from bulls fed with diets containing green tea by-product and bio-char was lowered than that compares to those fed with control diet $(p<0.05)$. Especially those fed with diet containing $5 \%$ green tea by-product (or diet containing $1.25 \%$ tannin) and $1 \%$ bio-char had the lowest methane emission which was reduced by 12.6 1/animal/day (by 6.96\%). It can be explained that tannin content of green tea by-product that brought up the tannin content in the diet up to $1.25 \%$ has impaired methane formation due to the reduction of rumen degradation [18]. On the other hand, tannin content in the diet also prevent the development of protozoa and other hydrogenesis bacteria [18] [19], and thus reduced hydrogen source for methane formation in the rumen.

Our findings was also supported by the findings of Tiemann et al. [5], when tannin from Calliandra calothyrsus and Flemingi amacrophyll were added into Swiss white sheep diet at $1.11 \%-1.75 \%$ DM which reduced methan emission by $3 \%-21 \%$.

Similarly, Hu et al. [20], reported that the inclusion of $1 \%, 2 \%, 3 \%$ and $4 \%$ of tannin into diet containing corn meal and grass meal (ratio of 50/50) had resulted in methane emission declined from $13 \%, 22 \%, 25 \%$ and $26 \%$, respectively, and they also found that the protozoa population declined from 19\%, 25\%, 45\% and $79 \%$, respectively, after 24 hours of incubation with rumen juice.

\subsection{Nutrients Intake, Growth and Methane Emission Intensity}

The data of nutrients intake, growth and methane emission are presented in Table 5. It can be seen that there was the lower methane emission in accordant 
Table 4. Methane and Carbon dioxide emission from experimental animals.

\begin{tabular}{|c|c|c|c|c|c|c|c|c|c|c|c|}
\hline \multirow{2}{*}{ Category } & \multicolumn{2}{|c|}{ Control } & \multicolumn{2}{|c|}{ DIET1 } & \multicolumn{2}{|c|}{ DIET2 } & \multicolumn{2}{|c|}{ DIET3 } & \multicolumn{2}{|c|}{ DIET4 } & \multirow{2}{*}{ P (Sig. } \\
\hline & Mean & $\mathrm{Se}$ & Mean & $\mathrm{Se}$ & Mean & $\mathrm{Se}$ & Mean & $\mathrm{Se}$ & Mean & $\mathrm{Se}$ & \\
\hline $\mathrm{CH}_{4}(\mathrm{l} /$ day $)$ & $180.88^{\mathrm{a}}$ & 0.90 & $177.50^{\mathrm{ab}}$ & 0.74 & $176.05^{\mathrm{b}}$ & 0.95 & $172.28^{\mathrm{cd}}$ & 1.44 & $168.28^{\mathrm{d}}$ & 0.48 & 0.000 \\
\hline Heat production (MJ) & $20.14^{\mathrm{a}}$ & 0.57 & $19.74^{\mathrm{abc}}$ & 0.55 & $18.53^{\mathrm{bc}}$ & 0.35 & $18.44^{\mathrm{c}}$ & 0.15 & $19.75^{\mathrm{ac}}$ & 0.20 & 0.005 \\
\hline $\mathrm{CO}_{2}$ (1/day) & $925.92^{\mathrm{a}}$ & 2.65 & $907.66^{\mathrm{abc}}$ & 25.66 & $852.22^{\mathrm{bc}}$ & 16.35 & $848.15^{\mathrm{c}}$ & 7.33 & $908.23^{\mathrm{ac}}$ & 9.33 & 0.005 \\
\hline $\mathrm{CH}_{4} / \mathrm{CO}_{2}$ & $0.195^{\mathrm{abc}}$ & 0.001 & $0.196^{\mathrm{abc}}$ & 0.006 & $0.207^{\mathrm{ac}}$ & 0.005 & $0.203^{c}$ & 0.003 & $0.185^{\mathrm{b}}$ & 0.002 & 0.012 \\
\hline
\end{tabular}

Note: The different subscript letters in the same row are significant different $(p<0.05)$.

Table 5. Nutrients intake, growth and methane emission intensity.

\begin{tabular}{|c|c|c|c|c|c|c|c|c|c|c|c|}
\hline \multirow{2}{*}{ Categories } & \multicolumn{2}{|c|}{ Control } & \multicolumn{2}{|c|}{ Diet 1} & \multicolumn{2}{|c|}{ Diet 2} & \multicolumn{2}{|c|}{ Diet 3} & \multicolumn{2}{|c|}{ Diet 4} & \multirow{2}{*}{ P (Sig.) } \\
\hline & Mean & $\mathrm{Se}$ & Mean & $\mathrm{Se}$ & Mean & $\mathrm{Se}$ & Mean & $\mathrm{Se}$ & Mean & $\mathrm{Se}$ & \\
\hline $\begin{array}{c}\mathrm{CH}_{4} / \mathrm{DM} \\
(\mathrm{l} / \mathrm{kg} / \text { day })\end{array}$ & $64.47^{\mathrm{a}}$ & 0.40 & $62.22^{\mathrm{ab}}$ & 0.46 & $61.22^{\mathrm{b}}$ & 0.40 & $59.35^{\mathrm{cd}}$ & 0.41 & $57.40^{\mathrm{d}}$ & 0.22 & 0.000 \\
\hline $\begin{array}{c}\mathrm{CH}_{4} / \mathrm{DM} \\
\text { (g/kg/day) }\end{array}$ & $45.77^{\mathrm{a}}$ & 0.28 & $44.18^{\mathrm{ab}}$ & 0.33 & $43.47^{\mathrm{b}}$ & 0.28 & $42.14^{\mathrm{cd}}$ & 0.29 & $40.76^{\mathrm{d}}$ & 0.16 & 0.000 \\
\hline $\begin{array}{l}\mathrm{CH}_{4} / \mathrm{NDF} \\
(\mathrm{l} / \mathrm{kg} / \text { day })\end{array}$ & $105.18^{\mathrm{a}}$ & 0.65 & $102.52^{\mathrm{ab}}$ & 0.76 & $101.59^{\mathrm{b}}$ & 0.67 & $97.98^{\mathrm{cd}}$ & 0.68 & $95.45^{\mathrm{d}}$ & 0.37 & 0.000 \\
\hline $\begin{array}{l}\mathrm{CH}_{4} / \mathrm{ADF} \\
(1 / \mathrm{kg} / \text { day })\end{array}$ & $199.59^{\mathrm{a}}$ & 1.23 & $194.44^{\mathrm{ab}}$ & 1.45 & $192.63^{b}$ & 1.26 & $185.72^{\mathrm{cd}}$ & 1.29 & $180.91^{\mathrm{d}}$ & 0.71 & 0.000 \\
\hline $\begin{array}{c}\mathrm{CH}_{4} / \mathrm{kg} \text { gain } \\
\text { (1/kg gain) }\end{array}$ & $283.81^{\mathrm{a}}$ & 3.16 & $269.38^{\mathrm{a}}$ & 8.77 & $244.52^{\text {bd }}$ & 4.45 & $230.60^{c d}$ & 2.05 & $246.10^{\mathrm{d}}$ & 5.51 & 0.000 \\
\hline
\end{tabular}

Note: The different subscript letters in the same row are significant different $(p<0.05)$.

with the increase level of tannin content in the diet $(P<0.05)$. When there was no tannin present in the diet (the control), methane emission was the highest $64.47 \mathrm{l} / \mathrm{kg} \mathrm{DM} /$ day, or $45.77 \mathrm{~g} / \mathrm{kg} \mathrm{DM} /$ day. When there was a presence of bio-char at $0.5 \%$ and tannin at $1.25 \%$ in the diet this emission was significantly the lowest at $57.40 \mathrm{l} / \mathrm{kg} \mathrm{DM} /$ day or $40.76 \mathrm{~g} / \mathrm{kg} \mathrm{DM} /$ day $(p<0.05)$.

The monitoring data of methane emission based on bodyweight gain during 0 - 90 days of experimental period revealed that diet without tannin content (control) had the largest methane emission capacity (283 1/kg BW gain). This emission of diet 3 (with $0.5 \%$ bio-char and $5 \%$ green tea by-product) was the lowest $(230.60 \mathrm{l} / \mathrm{kg}$ BW gain) $(p<0.05)$. When compares among the experimental diets with addition of green tea by-product and bio-char, the higher level of supplement, the amount of methane emission per each $\mathrm{kg}$ BW gain was reduced. However, when bio-char was added at $1 \%$ and green tea by-product at $5 \%$, this emission was increased significantly $(p<0.05)$.

According to O'Mara et al. [21] the better growth in animals was obtained via better nutrition, so that energy requirement for maintenance was calculated base on total energy requirement, so when energy loss via $\mathrm{CH} 4$ was reduced, the amount of methane emission per each $\mathrm{kg}$ of milk or meat produced was also reduced. Therefore, when $0.5 \%$ of bio-char and $5 \%$ of green tea by-product were 
Table 6. Methane emission based on total digestible nutrients.

\begin{tabular}{|c|c|c|c|c|c|c|c|c|c|c|c|}
\hline \multirow{2}{*}{ Category } & \multicolumn{2}{|c|}{ Control } & \multicolumn{2}{|c|}{ Diet 1} & \multicolumn{2}{|c|}{ Diet 2} & \multicolumn{2}{|c|}{ Diet 3} & \multicolumn{2}{|c|}{ Diet 4} & \multirow{2}{*}{ P (Sig.) } \\
\hline & Mean & $\mathrm{Se}$ & Mean & $\mathrm{Se}$ & Mean & $\mathrm{Se}$ & Mean & $\mathrm{Se}$ & Mean & $\mathrm{Se}$ & \\
\hline $\begin{array}{c}\mathrm{CH}_{4} / \mathrm{DM} \\
(1 / \mathrm{kg} / \text { day })\end{array}$ & $91.57^{\mathrm{a}}$ & 0.91 & $83.82^{\mathrm{bc}}$ & 0.71 & $82.58^{c}$ & 0.91 & $78.08^{\mathrm{de}}$ & 0.76 & $78.34^{\mathrm{e}}$ & 0.62 & 0.000 \\
\hline $\begin{array}{c}\mathrm{CH}_{4} / \mathrm{OM} \\
(1 / \mathrm{kg} / \text { day })\end{array}$ & $229.19^{\mathrm{a}}$ & 1.49 & $219.25^{\mathrm{b}}$ & 2.12 & $215.71^{\text {ce }}$ & 0.83 & $201.49^{\mathrm{d}}$ & 2.14 & $211.67^{e}$ & 1.09 & 0.000 \\
\hline $\begin{array}{l}\mathrm{CH}_{4} / \mathrm{NDF} \\
(1 / \mathrm{kg} / \text { day })\end{array}$ & $147.17^{\mathrm{a}}$ & 0.43 & $138.81^{\mathrm{bc}}$ & 1.26 & $137.44^{\mathrm{c}}$ & 0.83 & $126.54^{\mathrm{d}}$ & 1.10 & $131.70^{\mathrm{e}}$ & 0.82 & 0.000 \\
\hline $\begin{array}{l}\mathrm{CH}_{4} / \mathrm{ADF} \\
(1 / \mathrm{kg} / \text { day })\end{array}$ & $315.98^{\mathrm{a}}$ & 2.30 & $285.22^{\text {ce }}$ & 0.94 & $287.09^{c}$ & 2.78 & $260.36^{\mathrm{d}}$ & 0.59 & $276.65^{\mathrm{e}}$ & 2.06 & 0.000 \\
\hline
\end{tabular}

Note: The different subscript letters in the same row are significant different $(p<0.05)$.

added into diet there was a better in nutrients utilization efficiency compare to others.

\subsection{Methane Emission Based on Total Digestible Nutrients}

The data on the effect of bio-char and green tea by-product inclusion into diet on methane emission based on the total digestible nutrients is presented in $\mathrm{Ta}$ ble 6.

The total digestible nutrients included dry matter (DM), organic matter $(\mathrm{OM})$, neutral detergent fibre (NDF) and acid detergent fibre (ADF), data presented in Table 6 showed that methane emission tend to be lowered when difference bio-char and green tea by-product were added into diet, as in the control, this emission was $91.57 \mathrm{l} / \mathrm{kg}$ digestible DM and $229.19 \mathrm{l} / \mathrm{kg}$ digestible OM; whereas, with inclusion of diet 3 ( $0.5 \%$ bio-char and $5 \%$ green tea by-product), this emission was significantly $(p<0.05)$ the lowest $(78.08 \mathrm{l} / \mathrm{kg}$ digestible DM and 201.49 1/kg digestible OM.

This can be explained that when the nutrients digestibility was improved it increased the nutrients uptake and increased ingesta passage rate thus decreased fermentation time that resulted in reduction of methane production [22].

\section{Conclusion}

Bio-char and green tea by-product included into diet with different levels had significantly affected on the feed intake, as the increased level of tannin level in the diet tended to increase the feed intake. The inclusion of green tea by-product in the diet which resulted in the content of tannin in the diet of $12.5 \mathrm{~g} / \mathrm{kg} \mathrm{DM}$ had significantly reduced methane emission without altering animal performance, thus the inclusion of $0.5 \%$ bio-char and $5 \%$ of green tea by-product can be applied in order to mitigate methane emission, thus contributed to environment protection.

\section{Acknowledgements}

Authors of this article would like to express the sincerest thank for the financial 
support from the Ministry of Education and Training-Vietnam via the Ministry Project number B2016-TNA-02.

\section{References}

[1] Lovett, D., Stack, L., Lovell, S., Callan, J., Flynn, B., Hawkins, M. and O’Mara, F. (2005) Manipulating Enteric Methane Emissions and Animal Performance of Late-Lactation Dairy Cows through Concentrate Supplementation at Pasture. Journal of Dairy Science, 88, 2836-2842. https://doi.org/10.3168/jds.S0022-0302(05)72964-7

[2] Ungerfeld, E., Rust, S.R., Burnett, R.J., Yokoyama, M.T. and Wang, J. (2005) Effects of Two Lipids on in Vitro Ruminal Methane Production. Animal Feed Science and Technology, 119, 179-185. https://doi.org/10.1016/j.anifeedsci.2004.12.007

[3] Van Nevel, C. and Demeyer, D. (1996) Control of Rumen Methanogenesis. Environmental Monitoring and Assessment, 42, 73-97. https://doi.org/10.1007/BF00394043

[4] Ushida, K. and Jouany, J. (1996) Methane Production Associated with Rumen-Ciliated Protozoa and Its Effect on Protozoan Activity. Letters in Applied Microbiology, 23, 129-132. https://doi.org/10.1111/j.1472-765X.1996.tb00047.x

[5] Tiemann, T.T., Lascano, C.E., Wettstein, H.-R., Mayer, A.C., Kreuzer, M. and Hess, H.D. (2008) Effect of the Tropical Tannin-Rich Shrub Legumes Calliandra calothyrsus and Flemingia macrophylla on Methane Emission and Nitrogen and Energy Balance in Growing Lambs. Animal, 2, 790-799. https://doi.org/10.1017/S1751731108001791

[6] Grainger, C., Clarke, T., Auldist, M., Beauchemin, K., McGinn, S., Waghorn, G. and Eckard, R.J. (2009) Potential Use of Acacia mearnsii Condensed Tannins to Reduce Methane Emissions and Nitrogen Excretion from Grazing Dairy Cows. Canadian Journal of Animal Science, 89, 241-251. https://doi.org/10.4141/CJAS08110

[7] Hariadi, B.T. and Santoso, B. (2010) Evaluation of Tropical Plants Containing Tannin on in Vitro Methanogenesis and Fermentation Parameters Using Rumen Fluid. Journal of the Science of Food and Agriculture, 90, 456-461.

[8] Joseph, S., Doug, P., Dawson, K., Mitchell, D.R., Rawal, A., James, H. and Munroe, P. (2015) Feeding Biochar to Cows: An Innovative Solution for Improving Soil Fertility and Farm Productivity. Pedosphere, 25, 666-679.

https://doi.org/10.1016/S1002-0160(15)30047-3

[9] Pereira, R.C., Muetzel, S., Arbestain, M.C., Bishop, P., Hina, K. and Hedley, M. (2014) Assessment of the Influence of Biochar on Rumen and Silage Fermentation: A Laboratory-Scale Experiment. Animal Feed Science and Technology, 196, 22-31. https://doi.org/10.1016/j.anifeedsci.2014.06.019

[10] Roberts, K.G., Gloy, B.A., Joseph, S., Scott, N.R. and Lehmann, J. (2009) Life Cycle Assessment of Biochar Systems: Estimating the Energetic, Economic, and Climate Change Potential. Environmental Science \& Technology, 44, 827-833. https://doi.org/10.1021/es902266r

[11] Khang, D.N. and Wiktorsson, H. (2006) Performance of Growing Heifers Fed Urea Treated Fresh Rice Straw Supplemented with Fresh, Ensiled or Pelleted Cassava Foliage. Livestock Science, 102, 130-139. https://doi.org/10.1016/j.livsci.2005.12.003

[12] Steel, R. and Torrie, J.C. (1980) Principles and Procedures of Statistics: A Biometrical Approach. McGraw-Hill, New York.

[13] Barry, T. and Manley, T. (1984) The Role of Condensed Tannins in the Nutritional 
Value of Lotus pedunculatus for Sheep: 2. Quantitative Digestion of Carbohydrates and Proteins. British Journal of Nutrition, 51, 493-504. https://doi.org/10.1079/BJN19840055

[14] Barry, T., Manley, T. and Duncan, S. (1986) The Role of Condensed Tannins in the Nutritional Value of Lotus pedunculatus for Sheep: 4. Sites of Carbohydrate and Protein Digestion as Influenced by Dietary Reactive Tannin Concentration. British Journal of Nutrition, 55, 123-137. https://doi.org/10.1079/BJN19860016

[15] Waghorn, G., Shelton, I. and McNabb, W. (1994) Effects of Condensed Tannins in Lotus pedunculatus on Its Nutritive Value for Sheep. 1. Non-Nitrogenous Aspects. The Journal of Agricultural Science, 123, 99-107. https://doi.org/10.1017/S0021859600067824

[16] Leng, R., Preston, T. and Inthapanya, S. (2012) Biochar Reduces Enteric Methane and Improves Growth and Feed Conversion in Local "Yellow" Cattle Fed Cassava Root Chips and Fresh Cassava Foliage. Livestock Research for Rural Development, 24, No. 11. http://www.lrrd.cipav.org.co/lrrd24/11/leng24199.htm

[17] Leng, R. (2014) Interactions between Microbial Consortia in Biofilms: A Paradigm Shift in Rumen Microbial Ecology and Enteric Methane Mitigation. Animal Production Science, 54, 519-543. https://doi.org/10.1071/AN13381

[18] Tavendale, M.H., Meagher, L.P., Pacheco, D., Walker, N., Attwood, G.T. and Sivakumaran, S. (2005) Methane Production from in Vitro Rumen Incubations with Lotus pedunculatus and Medicago sativa, and Effects of Extractable Condensed Tannin Fractions on Methanogenesis. Animal Feed Science and Technology, 123-124, 403-419. https://doi.org/10.1016/j.anifeedsci.2005.04.037

[19] Patra, A.K. (2010) Meta-Analyses of Effects of Phytochemicals on Digestibility and Rumen Fermentation Characteristics Associated with Methanogenesis. Journal of the Science of Food and Agriculture, 90, 2700-2708. https://doi.org/10.1002/jsfa.4143

[20] Hu, W.-L., Liu, J.-X., Ye, J.-A., Wu, Y.-M. and Guo, Y.-Q. (2005) Effect of Tea Saponin on Rumen Fermentation in Vitro. Animal Feed Science and Technology, 120, 333-339. https://doi.org/10.1016/j.anifeedsci.2005.02.029

[21] O’Mara, F.P., Beauchemin, K., Kreuzer, M. and McAllister, T.A. (2008) Reduction of Greenhouse Gas Emissions of Ruminants through Nutritional Strategies. In: Rowlinson, P., Steele, M. and Nevzaoui, A., Eds., Livestock and Global Climate Change, Cambridge University Press, Cambridge, 40-43.

[22] Kongvongxay, S., Preston, T., Leng, R. and Khang, D.N. (2011) Effect of a Tannin-Rich Foliage (Mimosa pigra) on Feed Intake, Digestibility, N Retention and Methane Production in Goats Fed a Basal Diet of Muntingiacalabura. Livestock Research for Rural Development, 23, No. 3.

http://lrrd.cipav.org.co/lrrd23/3/sito23048.htm 